\title{
Syntheses, crystal structure and spectroscopic characterization of novel $N$-R-sulfonyldithiocarbimate zinc(II) complexes
}

\author{
Genivaldo J. Perpétuo ${ }^{\mathrm{a}, *}$, Marcelo R.L. Oliveira ${ }^{\mathrm{b}}$, Jan Janczak ${ }^{\mathrm{c}, \mathrm{d}}$, Heulla P. Vieira ${ }^{\mathrm{b}}$, \\ Fabiana F. Amaral ${ }^{\text {b }}$, Vito M. De Bellis ${ }^{\mathrm{d}}$ \\ a Departamento de Física, Instituto de Ciências Exatas e Biológicas, Universidade Federal de Ouro Preto, Ouro Preto MG, CEP 35400-000, Brazil \\ b Departamento de Química, Universidade Federal de Viçosa, Viçosa MG, CEP 36571-000, Brazil \\ ${ }^{\mathrm{c}}$ Institute of Low Temperature and Structure Research, Polish Academy of Science, P.O. Box 1410, Wrockaw 50-950, Poland \\ d Departamento de Química, Instituto de Ciências Exatas, Universidade Federal de Minas Gerais, Belo Horizonte MG, CEP 31270-901, Brazil
}

Received 23 April 2003; accepted 5 August 2003

\begin{abstract}
Two new compounds of the general formula: $\left(\mathrm{Ph}_{4} \mathrm{P}\right)_{2}\left[\mathrm{Zn}\left(\mathrm{RSO}_{2} \mathrm{~N}=\mathrm{CS}_{2}\right)_{2}\right]$, where $\mathrm{R}=\mathrm{C}_{6} \mathrm{H}_{5}$ (1) and 4- $\mathrm{CH}_{3} \mathrm{C}_{6} \mathrm{H}_{4}(\mathbf{2})$ were obtained in crystalline form by the reaction of the appropriate potassium $N$-R-sulfonyldithiocarbimate $\left(\mathrm{RSO}_{2} \mathrm{~N}=\mathrm{CS}_{2} \mathrm{~K}_{2}\right)$ with zinc(II) acetate dihydrate in dimethylformamide. The compounds crystallise in the centrosymmetric space group of the triclinic system with $Z=2$. The single crystal X-ray analysis showed a similarly distorted tetrahedral configuration around the zinc(II) cation due to the bidentate chelation by two sulfur atoms of the $N$-R-sulfonyldithiocarbimate ligands. Ionic interaction between oppositely charged moieties, i.e., the bis( $N$-R-sulfonyldithiocarbimato)zincate(II) dianion $\left[\mathrm{Zn}\left(\mathrm{RSO}_{2} \mathrm{~N}_{2} \mathrm{CS}_{2}\right)_{2}\right]^{2-}$ and tetraphenylphosphonium cation $\mathrm{Ph}_{4} \mathrm{P}^{+}$and van der Waals interactions determine the crystal packing motif. The IR data are consistent with the formation of zinc-dithiocarbimate complexes. The ${ }^{1} \mathrm{H}$ NMR and ${ }^{13} \mathrm{C}$ NMR spectra showed the expected signals for the tetraphenylphosphonium cation and the dithiocarbimate moieties.
\end{abstract}

(C) 2003 Elsevier Ltd. All rights reserved.

Keywords: Dithiocarbimates; Zinc complexes; Crystal structure; NMR; IR-spectroscopy

\section{Introduction}

Compounds containing zinc-sulfur-coordinated bonds have a wide range of application. For example, the $\mathrm{Zn}(\mathrm{II})$-dithiocarbimate complexes are worldwide used in the rubber vulcanization process [1-7]. Several dithiocarbimate and $N$-substituted dithiocarbimate complexes and salts have been used as fungicides and pesticides mainly due to their high efficiency in controlling plant fungal diseases and relatively low toxicity [8-15]. 1,1-Dithiolates have been used for the removal of heavy metals cations from the mammalian systems $[3,16]$. Zinc dithiolates are used in metal organic chemical vapour deposition (MOCVD) processes for the growth of semiconductor $\mathrm{ZnS}$ films [17-21]. In all these applications, the use of anionic zinc-sulfur compounds

\footnotetext{
${ }^{*}$ Corresponding author. Tel./fax: +55-31-35591667.

E-mail address: perpetuo@iceb.ufop.br (G.J. Perpétuo).
}

could be important. Vulcanization is greatly facilitated by the presence of anionic species. For example, vulcanizing mixtures containing $\left[\mathrm{Zn}\left(\mathrm{Me}_{2} \mathrm{NCS}_{2}\right)_{3}\right]^{-}$are faster accelerators of vulcanization than mixtures containing $\left[\mathrm{Zn}\left(\mathrm{Me}_{2} \mathrm{NCS}_{2}\right)_{2}\right]$ [7]. The improvement of the anti-fungi activity is another interesting possibility either by the use of active counter ions or by the variation on the solubility of the salts of the complexes by the use of different cations. The variation on the solubility could also be important in the extraction of toxic metals, like cadmium, from biological systems [22]. In the MOCVD techniques, changing the counter ions could increase the salt volatility favouring an ideal film formation. As the zinc(II)-bisdithiocarbimate complexes are necessarily anionic species, it should be interesting to prepare and study this class of compounds.

Our interest in the syntheses and characterization of dithiocarbimate-metal complexes or salts is due to their similarities with the dithiocarbamate complexes. Earlier 
we have synthesized and characterized three novel nickel(II) complexes with $N$-R-sulfonyldithiocarbimate and triphenylphosphine ligands [23]. Here, we investigate two new zinc(II)-bis( $N$-R-sulfonyldithiocarbimate) anionic complexes that were isolated as tetraphenylphosphonium salts with the general formula of $\left(\mathrm{Ph}_{4} \mathrm{P}\right)_{2}\left[\mathrm{Zn}\left(\mathrm{RSO}_{2} \mathrm{~N}=\mathrm{CS}_{2}\right)_{2}\right]$, where $\mathrm{R}=\mathrm{C}_{6} \mathrm{H}_{5}(\mathbf{1})$ and 4$\mathrm{CH}_{3} \mathrm{C}_{6} \mathrm{H}_{4}$ (2). These compounds were obtained in the crystalline form by the reaction of $\mathrm{Zn}\left(\mathrm{CH}_{3} \mathrm{COO}\right)_{2} \cdot 2 \mathrm{H}_{2} \mathrm{O}$ with dithiocarbimate anions derived from sulfonamides and tetraphenylphosphonium chloride. The complexes were characterized by the single crystal X-ray diffraction technique and by IR, ${ }^{1} \mathrm{H}$ and ${ }^{13} \mathrm{C}$ NMR spectroscopy.

\section{Experimental}

\subsection{Methods and materials}

The solvents were purchased from Merck and used without further purification. The sulfonamides, zinc acetate dihydrate and tetraphenylphosphonium chloride were purchased from Aldrich. Carbon disulfide and potassium hydroxide were purchased from Vetec. The $N$-R-sulfonyldithiocarbimate-potassium salts dihydrate were prepared in dimethylformamide from sulfonamides analogously as described in the literature [24,25]. These salts, which are soluble in water and insoluble in most organic solvents, were recrystallized from hot ethanol/ water solution. Melting points were determined with Mettler FP5 equipment. Microanalyses for $\mathrm{C}, \mathrm{H}$ and $\mathrm{N}$ were obtained from a Perkin-Elmer $2400 \mathrm{CHN}$. Zinc was analysed by atomic absorption with a Hitachi Z8200 Atomic Absorption Spectrophotometer. The elemental analyses of both $\mathrm{Zn}$ complexes have been also carried out on an energy dispersive spectrometer. The IR spectra were recorded with a Perkin-Elmer 283 B infrared spectrophotometer using CsI pellets. The ${ }^{1} \mathrm{H}$ (400 MHz) and ${ }^{13} \mathrm{C}(100 \mathrm{MHz}) \mathrm{NMR}$ spectra were recorded with a Bruker Advance RX-400 spectrophotometer in $\mathrm{CDCl}_{3}$ with TMS as internal standard.

\subsection{Syntheses}

The syntheses of the zinc(II)- $N$-R-sulfonyldithiocarbimate complexes were performed according to
Scheme 1. Zinc(II) acetate dihydrate $(0.7 \mathrm{mmol})$ was added to a suspension of the appropriate potassium $\mathrm{N}$ $\mathrm{R}$-sulfonyldithiocarbimate dihydrate $(1.5 \mathrm{mmol})$ in DMF $(15 \mathrm{~mL})$. The mixture was stirred for $1.5 \mathrm{~h}$ at room temperature and filtered. Water $(15 \mathrm{~mL})$ and tetraphenylphosphonium chloride $(1.5 \mathrm{mmol})$ were added to the solution obtained. The mixture was stirred for 15 min and the obtained yellowish solid product was filtered, washed with distilled water and dried under reduced pressure for three days, yielding $\left(\mathrm{Ph}_{4} \mathrm{P}\right)_{2}$ $\left[\mathrm{Zn}\left(\mathrm{RSO}_{2} \mathrm{~N}=\mathrm{CS}_{2}\right)_{2}\right] \quad$ (ca. $60 \%$ ). Suitable colourless crystals for X-ray structure analysis were obtained after slow evaporation of the solutions of the compounds in dichloromethane/methanol/water.

2.2.1. Bis(tetraphenylphosphonium) bis( $N$-phenylsulfonyldithiocarbimato) zincate (II), $\left(\mathrm{Ph}_{4} \mathrm{P}\right)_{2}$ [ $\left.\mathrm{Zn}\left(\mathrm{S}_{2} \mathrm{CNSO}_{2} \mathrm{C}_{6} \mathrm{H}_{5}\right)_{2}\right]$ (1)

Elemental analysis: Found (Calc. for $\mathrm{C}_{62} \mathrm{H}_{50} \mathrm{~N}_{2} \mathrm{O}_{4}$ $\mathrm{P}_{2} \mathrm{~S}_{6} \mathrm{Zn}$ ): C, 61.55 (61.71); H, 4.31 (4.18); N, 2.24 (2.32); $\mathrm{O}, 5.42$ (5.30); P, 5.10 (5.13); S, 15.98 (15.94) and $\mathrm{Zn}$, $5.40(5.42) \%$. m.p. $\left({ }^{\circ} \mathrm{C}\right): 157.5-159.7$. IR (most intense bands) $\left(\mathrm{cm}^{-1}\right): 1368 \quad v(\mathrm{C}=\mathrm{N}) ; 1278 \quad v_{\text {ass }}\left(\mathrm{SO}_{2}\right) ; 1143$ $v_{\text {sym }}\left(\mathrm{SO}_{2}\right) ; 937 v_{\text {ass }}\left(\mathrm{CS}_{2}\right)$ and $339 v(\mathrm{ZnS}) .{ }^{1} \mathrm{H}$ NMR $(\delta)$ : 7.93-7.90 (m, 4H, H2 and H6 (R group)); 7.89-7.56 (m, $\left.40 \mathrm{H}, \mathrm{Ph}_{4} \mathrm{P}^{+}\right) ; 7.25-7.14(\mathrm{~m}, 6 \mathrm{H}, \mathrm{H} 3, \mathrm{H} 4$ and $\mathrm{H} 5(\mathrm{R}$ group)). ${ }^{13} \mathrm{C}\left\{{ }^{1} \mathrm{H}\right\}$ NMR $(\delta): 209.76\left(\mathrm{~N}=\mathrm{CS}_{2}\right) ; 143.42$ (C1); 127.52 (C2 and C6); 127.84 (C3 and C5); 130.42 (C4); tetraphenylphosphonium cation signals $(J(\mathrm{~Hz}))$ : $117.41\left(\mathrm{~d}, J=88.9, \mathrm{Cl}^{\prime}\right) ; 130.65\left(\mathrm{~d}, J=12.8, \mathrm{C}^{\prime}\right.$ and $\left.\mathrm{C} 6^{\prime}\right) ; 134.50\left(\mathrm{~d}, J=10.3, \mathrm{C}^{\prime}\right.$ and $\left.\mathrm{C}^{\prime}\right) ; 135.51(\mathrm{~d}$, $\left.J=3.0, \mathrm{C}^{\prime}\right)$.

\subsubsection{Bis(tetraphenylphosphonium) bis( N-4-methyl- phenylsulfonyldithiocarbimato) zincate $(\mathrm{II}),\left(\mathrm{Ph}_{4} \mathrm{P}\right)_{2}$ [ $\left.\mathrm{Zn}\left(\mathrm{S}_{2} \mathrm{CNSO}_{2} \mathrm{C}_{6} \mathrm{H}_{4} \mathrm{CH}_{3}\right)_{2}\right]:$ (2)}

Elemental analysis: Found (Calc. for $\mathrm{C}_{64} \mathrm{H}_{54} \mathrm{~N}_{2} \mathrm{O}_{4} \mathrm{P}_{2} \mathrm{~S}_{6} \mathrm{Zn}$ ): C, 62.08 (62.25); H, 4.56 (4.41); $\mathrm{N}, 2.29$ (2.27); O, 5.31 (5.18); P, 4.98 (5.02); S, 15.52 (15.58) and $\mathrm{Zn}, 5.26(5.29) \%$. m.p. $\left({ }^{\circ} \mathrm{C}\right): 167.3-168.7 . I R$ (most intense bands) $\left(\mathrm{cm}^{-1}\right): 1383 v(\mathrm{C}=\mathrm{N}) ; 1277$ $v_{\text {ass }}\left(\mathrm{SO}_{2}\right) ; 1141 v_{\text {sym }}\left(\mathrm{SO}_{2}\right) ; 930 v_{\text {ass }}\left(\mathrm{CS}_{2}\right)$ and $330 v(\mathrm{ZnS})$. ${ }^{1} \mathrm{H}$ NMR $(\delta)$ : 7.83-7.55 (m, 44H, H2, H6 (R group) and $\left.\mathrm{Ph}_{4} \mathrm{P}^{+}\right), 6.98(\mathrm{~d}(J=8.2 \mathrm{~Hz}), 4 \mathrm{H}, \mathrm{H} 3$ and, H5 ( group)) and $2.20\left(\mathrm{~s}, 6 \mathrm{H}, \mathrm{CH}_{3}\right),{ }^{13} \mathrm{C}\left\{{ }^{1} \mathrm{H}\right\}$ NMR $(\delta)$ : $209.29\left(\mathrm{~N}=\mathrm{CS}_{2}\right) ; 140.46(\mathrm{C} 1$ and $\mathrm{C} 4) ; 127.85(\mathrm{C} 2$ and

$$
\begin{aligned}
& 2 \mathrm{RSO}_{2} \mathrm{~N}=\mathrm{CS}_{2} \mathrm{~K}_{2} \cdot 2 \mathrm{H}_{2} \mathrm{O} \stackrel{\mathrm{Zn}\left(\mathrm{CH}_{3} \mathrm{COO}\right)_{2} \cdot 2 \mathrm{H}_{2} \mathrm{O}, 2 \mathrm{PPh}_{4} \mathrm{Cl}, \mathrm{DMF}}{\stackrel{-6 \mathrm{H}_{2} \mathrm{O},-2 \mathrm{KCl},-2 \mathrm{CH}_{3} \mathrm{COOK}}{\longrightarrow}\left(\mathrm{Ph}_{4} \mathrm{P}\right)_{2}\left[\mathrm{Zn}\left(\mathrm{RSO}_{2} \mathrm{~N}=\mathrm{CS}_{2}\right)_{2}\right]} \underset{\mathbf{1 , 2}}{\mathbf{1}\left(\mathrm{R}=\mathrm{C}_{6} \mathrm{H}_{5}\right)} \\
& \mathbf{2}\left(\mathrm{R}=4-\mathrm{CH}_{3} \mathrm{C}_{6} \mathrm{H}_{4}\right)
\end{aligned}
$$


C6); 128.04 (C3 and $\mathrm{C} 5) ; 21.31\left(\mathrm{CH}_{3}\right)$; tetraphenylphosphonium cation signals $(J(\mathrm{~Hz})): 129.33(\mathrm{~d}, J=54$, $\left.\mathrm{C1}^{\prime}\right) ; 134.29$ (t, $J=6, \mathrm{C}^{\prime}$ and $\left.\mathrm{C}^{\prime}\right) ; 128.33$ (t, $J=5, \mathrm{C}^{\prime}$ and $\left.\mathrm{C}^{\prime}\right) ; 130.75\left(\mathrm{~s}, \mathrm{C} 4^{\prime}\right)$.

\subsection{X-ray crystallography}

X-ray intensity data for both crystals were collected using graphite monochromatic Mo $\mathrm{K} \alpha$ radiation on a four-circle $\kappa$-geometry KUMA KM-4 diffractometer with a two-dimensional area CCD detector (in Department of Crystallography, Institute of Low Temperature and Structural Research, Polish Academy of Science, Wroclaw, Poland). The $\omega$-scan technique with $\Delta \omega=0.75^{\circ}$ for each image was used for data collection. The 960 images for six different runs covered about $95 \%$ of the Ewald sphere. Initially the lattice parameters were refined on about 150 reflections obtained from 40 images for eight runs with different orientation in the reciprocal space. Finally the lattice parameters were refined by least-squares methods based on all the reflections with $I>2 \sigma\left(F^{2}\right)$. One image was used as a standard for monitoring the stability of the crystals as well as for monitoring the data collection after every 40 images, and no correction on the relative intensity variation was necessary. Integration of the intensities, correction for Lorenz and polarization effects were performed using a KUMA K M-4 CCD program system [26]. The face-indexed analytical absorption was calculated using the SHELXTL program [27]. The structures were solved by direct methods using SHELXS of the SHELXL97 program [28]. The calculated E map revealed the $\mathrm{Zn}, \mathrm{S}, \mathrm{P}, \mathrm{O}, \mathrm{N}$ and most of the $\mathrm{C}$ atoms. The remaining $\mathrm{C}$ atoms were located from the difference Fourier synthesis. The structures were refined with the anisotropic thermal parameters for all non-hydrogen atoms. Difference Fourier maps gave electron density concentrations approximately located for all hydrogen atom positions; these positions were idealised (HFIX 43 for all $\mathrm{H}$ atoms of the phenyl rings with isotropic thermal parameters of $1.2 U_{\text {eq }}$ of the carbon atoms joined directly to the hydrogen atoms, and HFIX 137 for the $\mathrm{CH}_{3}$ group in the compound $\mathbf{2}$ with isotropic thermal parameters of $1.5 U_{\mathrm{eq}}$ of the methyl carbon atom). Final difference Fourier maps showed no peaks of chemical significance. Details of the data collection parameters and final agreement factors are collected in Table 1. Selected bond lengths and angles are listed in Table 2.

\section{Results and discussion}

Both compounds in solid state are quite stable at the ambient conditions. They are slightly soluble in water, methanol and ethanol, and are soluble in chloroform and dichloromethane. The ideal mixture of solvents used for crystallization of the compounds is methanol/water with some drops of dichloromethane. The low melting

Table 1

Crystal data, data collection and refinement details for $\mathbf{1}$ and $\mathbf{2}$

\begin{tabular}{|c|c|c|}
\hline Formula & $\mathrm{C}_{62} \mathrm{H}_{50} \mathrm{~N}_{2} \mathrm{O}_{4} \mathrm{P}_{2} \mathrm{~S}_{6} \mathrm{Zn}$ & $\mathrm{C}_{64} \mathrm{H}_{54} \mathrm{~N}_{2} \mathrm{O}_{4} \mathrm{P}_{2} \mathrm{~S}_{6} \mathrm{Zn}$ \\
\hline Molecular weight & 1206.71 & 1234.76 \\
\hline Crystal system & triclinic & triclinic \\
\hline Space group & $P \overline{1}$ & $P \overline{1}$ \\
\hline \multicolumn{3}{|l|}{ Unit cell dimensions: } \\
\hline$a, b, c(\AA)$ & $11.136(2), 16.273(3), 17.649(4)$ & 9.422(2), 17.582(4), 20.081(4) \\
\hline$\alpha, \beta, \gamma\left({ }^{\circ}\right)$ & 89.50(3), 79.49(3), 72.20(3) & $73.66(3), 82.79(3), 84.60(3)$ \\
\hline Volume, $V\left(\AA^{3}\right)$ & $2990.3(10)$ & $3160.9(12)$ \\
\hline$Z$ & 2 & 2 \\
\hline$D_{\text {calc. }}\left(\mathrm{g} / \mathrm{cm}^{3}\right)$ & 1.340 & 1.297 \\
\hline$D_{\text {obs. }}($ floatation $)\left(\mathrm{g} / \mathrm{cm}^{3}\right)$ & 1.34 & 1.29 \\
\hline Radiation, Mo K $\alpha(\AA)$ & 0.71073 & 0.71073 \\
\hline \multicolumn{3}{|l|}{ Index range: } \\
\hline$h$ & $-14 \rightarrow 10$ & $-13 \rightarrow 9$ \\
\hline$K$ & $-20 \rightarrow 20$ & $-23 \rightarrow 24$ \\
\hline$L$ & $-22 \rightarrow 22$ & $-27 \rightarrow 27$ \\
\hline Reflections collected & 25,635 & 29,512 \\
\hline Independent reflections & $12,671\left(R_{\text {int }}=0.0214\right)$ & $15,474\left(R_{\text {int }}=0.0609\right)$ \\
\hline Absorption coefficient, $\mu\left(\mathrm{mm}^{-1}\right)$ & 0.721 & 0.684 \\
\hline Correction: & $\begin{array}{l}\text { Lorenz and polarization, absorption, } \\
T_{\min }=0.7515, T_{\max }=0.9058\end{array}$ & $\begin{array}{l}\text { Lorenz and polarization, absorption, } \\
T_{\min }=0.832, T_{\max }=0.947\end{array}$ \\
\hline \multicolumn{3}{|l|}{ Refinement on $F^{2}$} \\
\hline$R\left(F^{2}>\sigma\right)$ & 0.0475 & 0.0688 \\
\hline$w R\left(F^{2}\right.$ all reflections $)$ & 0.1107 & 0.0796 \\
\hline Residual electron density $\left(\mathrm{e}^{-3}\right)$ & -0.513 and +0.762 & -0.755 and +1.001 \\
\hline
\end{tabular}


Table 2

Selected bond lengths $(\AA)$ and angles $\left(^{\circ}\right)$

\begin{tabular}{|c|c|c|}
\hline & 1 & 2 \\
\hline \multicolumn{3}{|l|}{ Bond lengths } \\
\hline $\mathrm{Zn} 1-\mathrm{S} 1$ & $2.344(2)$ & $2.321(2)$ \\
\hline $\mathrm{Zn} 1-\mathrm{S} 2$ & $2.336(2)$ & $2.365(2)$ \\
\hline $\mathrm{Zn} 1-\mathrm{S} 11$ & $2.363(2)$ & $2.321(2)$ \\
\hline $\mathrm{Zn} 1-\mathrm{S} 12$ & $2.320(2)$ & $2.379(2)$ \\
\hline $\mathrm{S} 1-\mathrm{C} 1$ & $1.742(3)$ & $1.758(6)$ \\
\hline $\mathrm{S} 2-\mathrm{C} 1$ & $1.749(4)$ & $1.716(6)$ \\
\hline $\mathrm{C} 1-\mathrm{N} 1$ & $1.297(4)$ & $1.333(6)$ \\
\hline $\mathrm{N} 1-\mathrm{S} 3$ & $1.632(3)$ & $1.621(5)$ \\
\hline $\mathrm{S} 3-\mathrm{O} 1$ & $1.448(3)$ & $1.420(4)$ \\
\hline $\mathrm{S} 3-\mathrm{O} 2$ & $1.432(3)$ & $1.444(4)$ \\
\hline $\mathrm{S} 3-\mathrm{C} 2$ & $1.763(4)$ & $1,773(6)$ \\
\hline $\mathrm{S} 11-\mathrm{C} 11$ & $1.849(5)$ & $1.740(7)$ \\
\hline $\mathrm{S} 12-\mathrm{C} 11$ & $1.714(4)$ & $1.791(6)$ \\
\hline $\mathrm{C} 11-\mathrm{N} 11$ & $1.252(4)$ & $1.313(7)$ \\
\hline N11-S13 & $1.642(4)$ & $1.601(5)$ \\
\hline $\mathrm{S} 13-\mathrm{O} 11$ & $1.381(3)$ & $1.437(4)$ \\
\hline $\mathrm{S} 13-\mathrm{O} 12$ & $1.472(3)$ & $1.478(4)$ \\
\hline $\mathrm{S} 13-\mathrm{C} 12$ & $1.779(4)$ & $1.750(7)$ \\
\hline \multicolumn{3}{|l|}{ Bond angles } \\
\hline $\mathrm{S} 1-\mathrm{Zn} 1-\mathrm{S} 2$ & $77.73(4)$ & 76.91(6) \\
\hline $\mathrm{S} 11-\mathrm{Zn} 1-\mathrm{S} 12$ & $78.33(5)$ & $77.56(6)$ \\
\hline $\mathrm{S} 1-\mathrm{Zn} 1-\mathrm{S} 11$ & $134.38(5)$ & $128.45(7)$ \\
\hline $\mathrm{S} 2-\mathrm{Zn} 1-\mathrm{S} 12$ & $126.78(5)$ & $134.87(7)$ \\
\hline $\mathrm{S} 1-\mathrm{Zn} 1-\mathrm{S} 12$ & $122.90(5)$ & $121.51(7)$ \\
\hline $\mathrm{S} 2-\mathrm{Zn} 1-\mathrm{S} 11$ & $124.47(5)$ & $125.77(7)$ \\
\hline $\mathrm{S} 1-\mathrm{C} 1-\mathrm{N} 1$ & $128.9(3)$ & $128.6(5)$ \\
\hline $\mathrm{S} 2-\mathrm{C} 1-\mathrm{N} 1$ & $116.5(2)$ & $117.4(5)$ \\
\hline $\mathrm{S} 1-\mathrm{C} 1-\mathrm{S} 2$ & $114.6(2)$ & $114.0(4)$ \\
\hline $\mathrm{C} 1-\mathrm{N} 1-\mathrm{S} 3$ & $123.0(2)$ & $119.9(4)$ \\
\hline $\mathrm{N} 1-\mathrm{S} 3-\mathrm{C} 2$ & $105.2(2)$ & $110.7(3)$ \\
\hline $\mathrm{N} 1-\mathrm{S} 3-\mathrm{O} 1$ & $113.6(2)$ & $114.6(3)$ \\
\hline $\mathrm{N} 1-\mathrm{S} 3-\mathrm{O} 2$ & $104.4(2)$ & $102.8(3)$ \\
\hline $\mathrm{C} 11-\mathrm{N} 11-\mathrm{S} 13$ & $127.0(3)$ & $121.5(5)$ \\
\hline $\mathrm{S} 11-\mathrm{C} 11-\mathrm{N} 11$ & $124.8(4)$ & $119.2(5)$ \\
\hline $\mathrm{S} 12-\mathrm{C} 11-\mathrm{N} 11$ & $122.3(4)$ & $127.9(5)$ \\
\hline $\mathrm{S} 11-\mathrm{C} 11-\mathrm{S} 12$ & $112.2(2)$ & $113.0(4)$ \\
\hline $\mathrm{N} 11-\mathrm{S} 13-\mathrm{C} 12$ & $102.5(2)$ & $109.0(3)$ \\
\hline $\mathrm{N} 11-\mathrm{S} 13-\mathrm{O} 11$ & $106.2(2)$ & $101.5(3)$ \\
\hline $\mathrm{N} 11-\mathrm{S} 13-\mathrm{O} 12$ & $113.2(2)$ & $116.0(3)$ \\
\hline $\mathrm{O} 11-\mathrm{S} 13-\mathrm{O} 12$ & $116.0(2)$ & $116.7(3)$ \\
\hline
\end{tabular}

points are desirable for liquid precursors in the MOCVD techniques. As compounds $\mathbf{1}$ and $\mathbf{2}$ have lower melting points (157.5-159.7 and 167.3-168.7 ${ }^{\circ} \mathrm{C}$, respectively) than either $\left[\mathrm{Zn}\left(\mathrm{Et}_{2} \mathrm{NCS}_{2}\right)_{2}\right]\left(178{ }^{\circ} \mathrm{C}\right)$ or $\left[\mathrm{Zn}\left(\mathrm{Me}_{2} \mathrm{NCS}_{2}\right)_{2}\right]$ (ca. $\left.250{ }^{\circ} \mathrm{C}\right)[17]$, they are potential precursors for $\mathrm{ZnS}$ film deposition. Furthermore, lower melting points might be obtained by replacing the $\mathrm{Ph}_{4} \mathrm{P}^{+}$ cation by other counter ion.

There are no strong or medium bands in the 1400 $1600 \mathrm{~cm}^{-1}$ region in the IR spectra of the compounds 1 and 2 as well as in the spectra of the potassium dithiocarbimates related to the compounds. The $v \mathrm{CN}$ band in the spectra of the potassium dithiocarbimates is observed at around $1260 \mathrm{~cm}^{-1}$ [29]. This low value indicates a great contribution of the canonical form (a) and (b) for the resonance hybrid in the dithiocarbimate potassium salts (Scheme 2). A strong band at 1368 and $1383 \mathrm{~cm}^{-1}$ observed in the spectra of the compounds $\mathbf{1}$ and $\mathbf{2}$, respectively, is assigned to the $v \mathrm{C}=\mathrm{N}$ vibration of the $\mathrm{RSO}_{2} \mathrm{~N}=\mathrm{CS}_{2}$ group. In the spectral region of 1300-1100 $\mathrm{cm}^{-1}$ two vibrational bands are observed. They are assigned to the sulfonyl $\mathrm{SO}_{2}$ group: one band at lower frequency is assigned to the symmetric vibration mode of the sulfonyl group $-v_{\text {sym }}\left(\mathrm{SO}_{2}\right)\left(1143\right.$ and $1141 \mathrm{~cm}^{-1}$ in the spectrum of $\mathbf{1}$ and $\mathbf{2}$, respectively) and one at higher frequency (1278 and $1277 \mathrm{~cm}^{-1}$ in $\mathbf{1}$ and $\mathbf{2}$, respectively) is assigned to the asymmetric $v_{\text {ass }}\left(\mathrm{SO}_{2}\right)$. The spectral region of $1000-900 \mathrm{~cm}^{-1}$ is characteristic for the disulfuric chelation [30]. The $v_{\text {ass }} \mathrm{CS}_{2}$ was observed at higher frequency in the spectra of the potassium salts of dithiocarbimates (ca. $955 \mathrm{~cm}^{-1}$ ) [29] than that in the spectra of the compounds here studied (937 and $930 \mathrm{~cm}^{-1}$ for 1 and 2 , respectively). The shifts observed in the $v_{\text {ass }} \mathrm{CS}_{2}$ and $v \mathrm{CN}$ in the spectra of the compounds here studied, when compared with the spectra of the ligands, are consistent with the increased importance of the canonical form (c) in both $\mathrm{Zn}$ complexes (Scheme 2). The spectra of the compounds also show the expected medium band in the $300-400 \mathrm{~cm}^{-1}$ range assigned to the $\mathrm{Zn}-\mathrm{S}$ stretching vibration indicating the gem-disulfur ligand [31]. Only one band being observed in the spectral region of $\mathrm{Zn}-\mathrm{S}$ stretching vibration may be explained by the fact that the differences between the $\mathrm{Zn}-\mathrm{S}$ bond lengths are relatively small, as shown by the X-ray single crystal analysis.

The NMR spectra showed the expected signals for the compounds. The ${ }^{1} \mathrm{H}$ NMR spectra showed the signals for the hydrogen atoms of the tetraphenylphosphonium cation. The remaining signals could be assigned to the $\mathrm{CH}_{3}$ group of the aromatic moiety and the other aromatic hydrogen atoms. The integration curves on the ${ }^{1} \mathrm{H}$ NMR spectra were consistent with a $2: 1$ proportion between the tetraphenylphosphonium cation and the bis $(N-\mathrm{R}$-sulfonyldithiocarbimato)zincate(II) dianions. The signals of the free $N$-R-sulfonyldithiocarbimates [29] and those of the $N$-R-sulfonyldithiocarbimate moieties of the compounds here studied show approximately the same chemical shifts. The ${ }^{13} \mathrm{C}$ NMR spectra showed, for both compounds, only five signals assigned to the dithiocarbimate moiety (the signals of $\mathrm{C} 1$ and $\mathrm{C} 4$ of compound 2

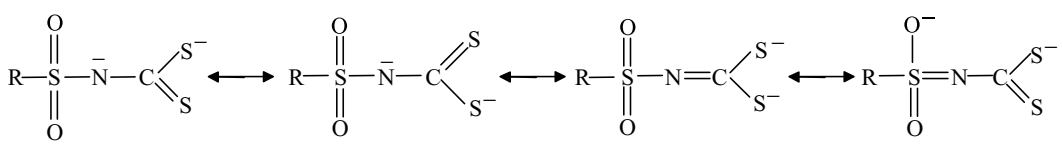

(a)

(b)

(c)

(d)

Scheme 2. 
were superimposed). This fact points to a magnetic equivalence of the corresponding atoms in both dithiocarbimate ligands in each compound in solution. The chemical shifts of the aromatic carbon atoms of the dithiocarbimate anions in the compounds are similar to those of the corresponding sulfonamides [32]. The $\mathrm{N}=\mathrm{CS}_{2}(\mathrm{Cl})$ signal is shifted in the spectra of the complexes to higher field if compared to the spectra of the ligands. Although the solvents are necessarily different, this shift is expected. If the canonical form (c) (Scheme 2) is more important for the complexes than for the ligands, then the $\mathrm{C} 1$ carbon atom is expected to be more shielded in the complexes.

The X-ray single crystal analysis of the two ionic complexes here studied are the first examples of this type of dithiocarbimate structures. The molecular structures of $\left(\mathrm{Ph}_{4} \mathrm{P}\right)_{2}\left[\mathrm{Zn}\left(\mathrm{S}_{2} \mathrm{CNSO}_{2} \mathrm{C}_{6} \mathrm{H}_{5}\right)_{2}\right]$ (1) and $\left(\mathrm{Ph}_{4} \mathrm{P}\right)_{2}$ $\left[\mathrm{Zn}\left(\mathrm{S}_{2} \mathrm{CNSO}_{2} \mathrm{C}_{6} \mathrm{H}_{4} \mathrm{CH}_{3}\right)_{2}\right]$ (2) are shown in Figs. 1(a) and (b), respectively. In both compounds the zinc atom is coordinated by four sulfur atoms of two $N$-R-sulfonyldithocarbimate ligands into a similarly distorted tetrahedral configuration due to the chelating effect of the ligands, which is clearly manifested in the $\mathrm{S}-\mathrm{Zn}-\mathrm{S}$ angles. The two $\mathrm{S}-\mathrm{Zn}-\mathrm{S}$ angles containing both sulfur atoms of the same $N$-R-sulfonyldithocarbimate chelating ligand (S1 and S2 or S11 and S12) are significantly
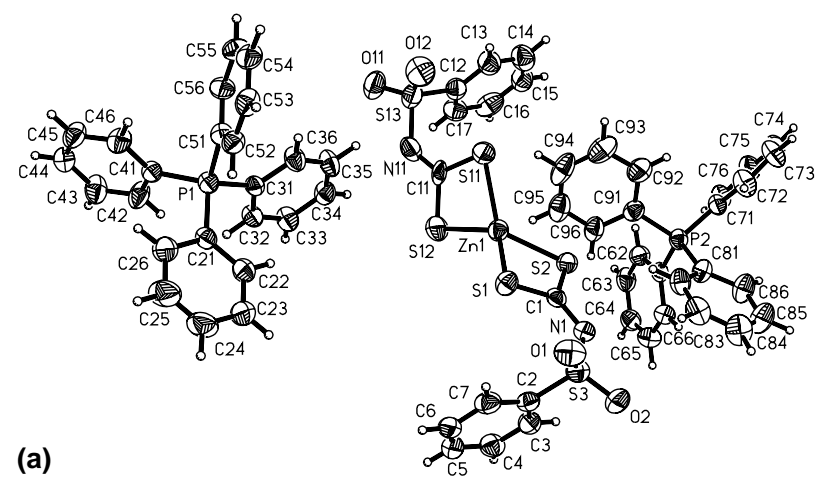

(a)

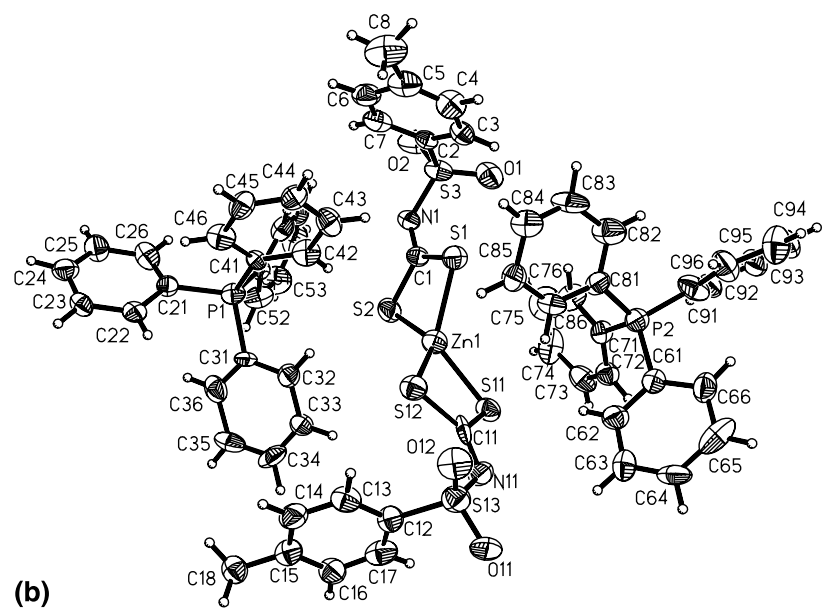

Fig. 1. View of the molecular structure of compounds 1 (a) and 2 (b). smaller, while the remaining four $\mathrm{S}-\mathrm{Zn}-\mathrm{S}$ angles containing the sulfur atoms of two $N$-R-sulfonyldithocarbimate chelating ligands are significantly greater than the angles observed for ideal $\mathrm{ZnS}_{4}$ tetrahedral geometry $\left(\sim 109.3^{\circ}\right)$. The $\mathrm{ZnS}_{4}$ coordination polyhedron is additionally distorted due to the interaction with the large tetraphenylphosphonium cations that can be illustrated by the deviation from $90^{\circ}$ (in an ideal tetrahedral) of the dihedral angle between the $\mathrm{Zn} 1, \mathrm{~S} 1, \mathrm{~S} 2$ and $\mathrm{Zn} 1, \mathrm{~S} 11$, S12 planes. This angle is equal to 83.4(3) and 82.0(3) in compound $\mathbf{1}$ and $\mathbf{2}$, respectively. The slightly greater deviation of the dihedral angle from $90^{\circ}$ for the compound $\mathbf{2}$ can be explained by the stereochemistry affecting the large $\mathrm{Ph}_{4} \mathrm{P}^{+}$cations that interact with the $p$ $\mathrm{CH}_{3}$ group of the $N$-R-sulfonyldithocarbimate chelating ligands coordinated to the $\mathrm{Zn}$ atom. The $N$-R-sulfonyldithocarbimate dianion $\left(\mathrm{RSO}_{2} \mathrm{~N}=\mathrm{CS}_{2}\right)^{2-}$ as bidentate ligands form stable four membered rings by chelation through the two sulfur atoms $\left(\mathrm{ZnS}_{2} \mathrm{C}\right)$.

The four $\mathrm{Zn}-\mathrm{S}$ bond lengths are ranging from 2.320(2) to 2.363(2) $\AA$ for compound $\mathbf{1}$ and they are compared with those observed in compound $\mathbf{2}$ (2.337(2)-2.377(2) A). The C1-N1 and C11-N11 bond lengths of 1.297(4) and 1.252(4) $\AA$, respectively, in compound $\mathbf{1}$ are shorter than in the $N$-phenylsulfonyldithiocarbimate potassium salt $\left(\mathrm{C}_{6} \mathrm{H}_{5} \mathrm{SO}_{2} \mathrm{~N}=\right.$ $\left.\mathrm{CS}_{2} \mathrm{~K}_{2}\right)(1.342(9) \AA)$ [25] and than those found in compound 2 (1.333(6) and 1.313(7) $\AA$, respectively). These values are shorter than the normal single $\mathrm{C}\left(\mathrm{sp}^{2}\right)-\mathrm{N}\left(\mathrm{sp}^{2}\right)$ bond length (ca. $1.35 \AA$ ). In compound 1 the $\mathrm{C}-\mathrm{N}$ bond lengths are similar to that of the double bond $\mathrm{C}\left(\mathrm{sp}^{2}\right)=\mathrm{N}\left(\mathrm{sp}^{2}\right)(1.273-1.295 \AA)$ [33,34], while in compound 2 the double character of this $\mathrm{C}-\mathrm{N}$ bond decreases. The $\mathrm{C}-\mathrm{S}$ bond lengths of both dithio $\mathrm{CS}_{2}$ chelating groups are very similar (average value of $1.748^{\circ}$ and are slightly shorter than the typical $\mathrm{C}-\mathrm{S}$ single bond length (ca. $1.81 \AA$ ) due to partial $\pi$-delocalization in the $\mathrm{S}-\mathrm{C}-\mathrm{S}$ groups. The $\mathrm{S} 1-\mathrm{C} 1-\mathrm{N} 1$ and $\mathrm{S} 11-\mathrm{C} 11-\mathrm{N} 11$ angles are significantly greater than $\mathrm{S} 2-\mathrm{C} 1-\mathrm{N} 1$ and $\mathrm{S} 12-\mathrm{C} 11-\mathrm{N} 11$ due to the interaction between the $\mathrm{SO}_{2} \mathrm{R}$ groups and $\mathrm{S} 1$ and $\mathrm{S} 11$ atoms, which are joined in cis positions in relation to the $\mathrm{C} 1-\mathrm{N} 1$ and C11-N11 bonds. The steric effect of the phenylsulfonyl or 4-methyl-phenylsulfonyl $\left(\mathrm{RSO}_{2}\right)$ groups are greater than the effect of the non-bonding lone-pair of electrons at the $\mathrm{N} 1$ and $\mathrm{N} 11$ atoms, since the $\mathrm{C} 1-\mathrm{N} 1-\mathrm{S} 3$ and $\mathrm{C} 11-\mathrm{N} 11-\mathrm{S} 13$ angles are greater than $120^{\circ}$ in both complexes. If the group linked to the $\mathrm{N}$ atom is small such as $-\mathrm{SO}_{2} \mathrm{CH}_{3}$ [35] or $-\mathrm{C} \equiv \mathrm{N}$ [36] groups the nonbonding effect of the lone-pair of electrons predicted by the valence-shell electron pair repulsion theory (VSEPR) $[37,38]$ is greater than the steric effect of these groups.

The Zn1, S1, S2, C1, N1, S3 (plane 1) and Zn1, S11, $\mathrm{S} 12, \mathrm{C} 11, \mathrm{~N} 11, \mathrm{C} 13$ (plane 2) fragments of the bis $(N-\mathrm{R}-$ sulfonyldithiocarbimato)zincate(II) dianion are almost planar, the greatest deviations of atoms from the 
weighted mean plane through the fragments are smaller than $\pm 0.1 \AA$. The dihedral angle between the abovementioned planes ( 1 and 2 ) is equal to $81.5(3)^{\circ}$ and $84.6(3)^{\circ}$ in compounds 1 and 2 , respectively. The planar $\mathrm{C} 2-\mathrm{C} 7$ phenyl ring is inclined by about $91.5(3)^{\circ}$ to plane 1 and the second $\mathrm{C} 12-\mathrm{C} 17$ phenyl ring is inclined by $87.4(3)^{\circ}$ to plane 2 in compound 1 , and the equivalent angles in compound 2 are $79.9(3)^{\circ}$ and $87.5(3)^{\circ}$, respectively. The $\mathrm{C} 1-\mathrm{N} 1-\mathrm{S} 3-\mathrm{C} 2$ and $\mathrm{N} 1-\mathrm{S} 3-\mathrm{C} 2-\mathrm{C} 3$ torsion angles for one $N$-R-sulfonyldithocarbimate ligand and the torsion angles of $\mathrm{C} 11-\mathrm{N} 11-\mathrm{S} 13-\mathrm{C} 12$ and $\mathrm{N} 11-\mathrm{S} 13-\mathrm{C} 12-\mathrm{C} 13$ for the second ligand describe the conformation of the ligands along the $\mathrm{N} 1-\mathrm{S} 3$ or N11-S13 bonds (see Fig. 1a) and the orientation of the planar phenyl rings (the second torsion angles). These angles are equal to $68.1(3)^{\circ}$ and $61.7(3)^{\circ}$ for the first ligand and $66.7(3)^{\circ}$ and $-124.1(3)^{\circ}$ for the second ligand in compound 1. The corresponding torsion angles in compound 2 (see Fig. 1(b)) are equal to $-63.4(3)^{\circ}$ and $113.2(3)^{\circ}$ for one ligand and $67.7(3)^{\circ}$ and $-129.5(3)^{\circ}$ for the second ligand, respectively. Thus the conformation of the ligands along N1-S3 and N11-S13 in the compound 1 is similar $\left[68.1(3)^{\circ}\right.$ and $\left.66.7(3)^{\circ}\right]$ and in compound 2 the conformation of one ligand [along N1-S3, $-63.4(3)^{\circ}$ ] is opposite to the other ligand [along N11-S13, 113.2(3) ${ }^{\circ}$.

The sulfonyl S3 and S13 atoms of both $N$-R-dithiocarbimate ligands have an expected distorted tetrahedral geometry. The $\mathrm{O} 1-\mathrm{S} 3-\mathrm{O} 2$ and $\mathrm{O} 11-\mathrm{S} 13-\mathrm{O} 12$ angles are significantly greater than the value for ideal tetrahedral geometry due to the steric effect of lone-pairs of electrons on both oxygen atoms. The $\mathrm{S} 3-\mathrm{O} 1$ and $\mathrm{S} 3-\mathrm{O} 2$ bond lengths indicate their double bond character $(\mathrm{S}=\mathrm{O})$; a typical distance of the double $\mathrm{S}=\mathrm{O}$ bond ranges from 1.418 to $1.442 \AA[34,36]$. The difference between the $\mathrm{S} 13-\mathrm{O} 11$ and $\mathrm{S} 13-\mathrm{O} 12$ bonds in compound 1 [1.381(3) and 1.472(3) $\mathrm{A}]$ is more obvious than in compound 2 in which all $\mathrm{S}-\mathrm{O}$ distances in the sulfonyl $-\mathrm{SO}_{2} \mathrm{R}$ groups are as expected. The chemically equivalent $\mathrm{S}-\mathrm{O}$ bond lengths of both $N$-R-sulfonyldithiocarbimate ligands in the compound $\mathbf{2}$ are very similar, however in the compound $\mathbf{1}$ the differences between the corresponding bonds of both $N$-R-sulfonyldithiocarbimate ligands, especially the above-mentioned S13-O11 and S13-O12 bonds are greater. These differences can be explained by the slightly single character of the $\mathrm{S} 13-\mathrm{O} 12$ bond (1.472(3) $\mathrm{A}$, this value is slightly longer than the normal double $\mathrm{S}=\mathrm{O}$ bond) with shortening the other $\mathrm{S} 13-\mathrm{O} 11$ bond in the sulfonyl $\mathrm{SO}_{2}$ group. These $\mathrm{S}-\mathrm{O}$ distances indicate a contribution of the canonical form (d) (Scheme 2) in one of the $N$-Rsulfonyldithiocarbimate ligands in compound 1 . The observed differences between the $\mathrm{S}-\mathrm{O}$ bonds of the $N$ $\mathrm{R}$-sulfonyldithiocarbimate ligand in the $\mathrm{X}$-ray experiment might be due to the greater anisotropic thermal parameters of $\mathrm{S} 13, \mathrm{O} 11$ and $\mathrm{O} 12$ in comparison to the other sulfonyl group (S3, O1, O2) indicating the possibility of disorder. However, when used for the sulfonyl group (atoms S13, O11, S12) some disorder models were not successful, thus the greater anisotropic thermal parameters (in relation to the other $\mathrm{SO}_{2}$ group) indicate rather on the greater molecular motion. The calculated corrections of the S13-O11 and S13-O12 bond lengths using the Schomaker and Trueblood [39] procedure for the librations indicate that the corrections of the $\mathrm{S}-\mathrm{O}$ bond lengths are not greater than $\pm 0.02 \AA$. Thus, most probably, as suggested before, the difference between the $\mathrm{S}-\mathrm{O}$ distances could be explained by the slightly single character of the $\mathrm{S} 13-\mathrm{O} 12$ bond as shows the resonance hybrid (d) (Scheme 2). The S3-C2 and S13-C12 bonds with distances of 1.763(4) and 1.779(4) $\AA$ in compound 1 and 1.773(6) and 1.750(7) $\AA$ in compound 2, respectively, correlate well with the distances of 1.749-1.798 $\AA$ for $\mathrm{C}_{\mathrm{ar}}-\mathrm{S}$ bonds in related complexes which comprise the $\mathrm{C}_{\mathrm{ar}}-\mathrm{SO}_{2}-\mathrm{N}$ fragment [34]. The $\mathrm{S} 3-\mathrm{N} 1$ and S13-N11 bond lengths with the average distance of $1.624 \AA$ indicate a single bond nature; the typical value of the $\mathrm{N}\left(\mathrm{sp}^{2}\right)-\mathrm{S}$ bond distance is 1.623-1.659 $\AA$ [34].

The arrangement of the molecules in the crystal 1 and 2 (see Figs. 2(a) and (b)) is mainly determined by the ionic interaction of the oppositely charged moieties, i.e., bis( $N$-R-sulfonyldithiocarbimato)zincate(II) dianion and tetraphenylphosphonium cations and by the van der

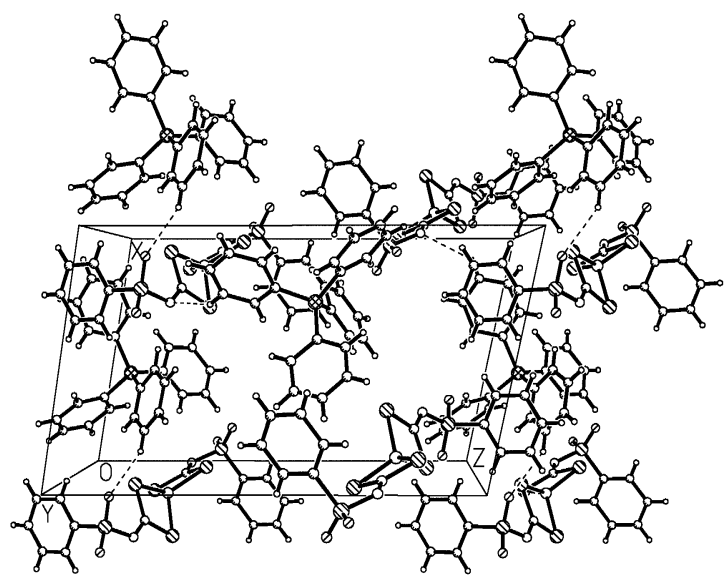

(a)

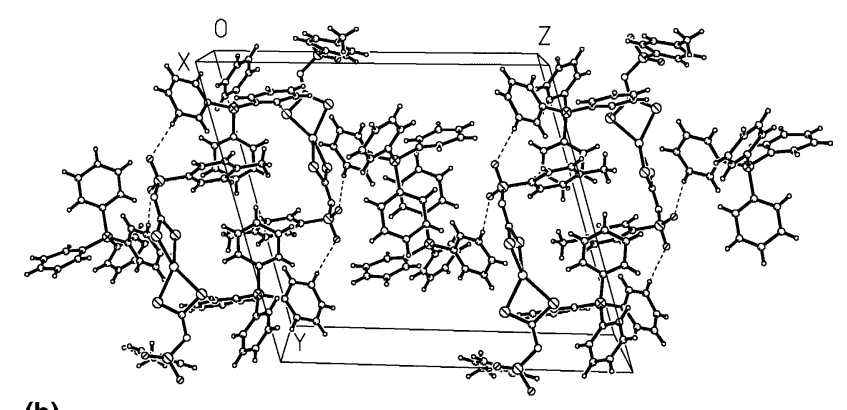

(b)

Fig. 2. Molecular arrangements of compounds $\mathbf{1}$ (a) and $\mathbf{2}$ (b) in the unit cells. 
Waals forces. The structures are slightly stabilized by the weak $\mathrm{C}-\mathrm{H} \cdots \mathrm{O}$ and $\mathrm{C}-\mathrm{H} \cdots \mathrm{N}$ interactions with the $\mathrm{C} \cdots \mathrm{O}$ and $\mathrm{C} \cdots \mathrm{N}$ distances of approximately 3.33 and $3.45 \AA$ in the crystal of 1 and 3.44 and $3.30 \AA$ in the crystal of 2, respectively. Although in both crystals the $\mathrm{C}-\mathrm{H} \cdots \mathrm{O}$ and $\mathrm{C}-\mathrm{H} \cdots \mathrm{N}$ interactions are weak, we suppose that they are important for the crystal packing. The usually weak $\mathrm{C}-\mathrm{H} \cdots \mathrm{N}$ and $\mathrm{C}-\mathrm{H} \cdots \mathrm{O}$ hydrogen bonds play a significant role in the formation and stabilisation of supramolecular architectures, especially in biological systems. The formation of a non-covalent association of proteins and ligands, formation of a phospholipid bilayer, interaction of a transcription factor with DNA, and folding of a tRNA into its threedimensional conformation are examples of processes that depend on noncovalent weak $\mathrm{C}-\mathrm{H} \cdots \mathrm{O}$ and $\mathrm{C}-\mathrm{H} \cdots \mathrm{N}$ interactions [40]. As can be seen from the crystal packing (Fig. 2) the hydrophobic phenyl rings of the $\mathrm{Ph}_{4} \mathrm{P}^{+}$cations are located close on both sides of the polar (hydrophilic) sulfonyl groups. This arrangement together with the weak $\mathrm{C}-\mathrm{H} \cdots \mathrm{O}$ and $\mathrm{C}-\mathrm{H} \cdots \mathrm{N}$ interactions are responsible for the observed only slightly solubility of these complexes in polar solvents like water, methanol or ethanol, as well as for the relatively low melting point.

\section{Conclusion}

Two novel anionic zinc(II) complexes with dithiocarbimates were obtained. Their tetraphenylphosphonium salts were isolated in crystalline form and characterized by IR, ${ }^{1} \mathrm{H}$ and ${ }^{13} \mathrm{C}$ NMR and by single crystal X-ray diffraction techniques. The single crystal $\mathrm{X}$-ray analysis and spectroscopic data show interesting correlations. The frequency value of the IR $v \mathrm{C}=\mathrm{N}$ vibration observed in the spectrum of compound $\mathbf{1}$ is greater than that observed for the free ligand (around $1260 \mathrm{~cm}^{-1}$ ) [29]. This observation is in agreement with the suggestion that the $\mathrm{C}-\mathrm{N}$ bond in the free ligand is more single ( $\mathrm{C}-\mathrm{N}, 1.342(9) \AA[25])$ and after complexation the double character of this $\mathrm{C}-\mathrm{N}$ bond increases. The NMR spectra show that carbon atoms $\mathrm{C} 1$ and $\mathrm{C} 11$ of the $\mathrm{N}$-R-sulfonyldithiocarbimate ligand of compound 1 are more shielded than that of the parent ligands [29]. This fact is in accordance with an increase of the contribution of the canonical form (c) (Scheme 2) to the resonance hybrid from the free ligand to the $\mathrm{Zn}$-complexes, and consequently with the increase of the $\mathrm{C}-\mathrm{N}$ double bond character.

\section{Supplementary material}

Crystallographic data for the structural analysis have been deposited with the Cambridge Crystallographic
Data Centre, CCDC Nos. 201751 and 201752 for 1 and 2, respectively. Copies of this information may be obtained free of charge from The director, CCDC, 12 Union Road, Cambridge, CB2 1EZ, UK (fax: +44 1223336-033; e-mail: deposit@ccdc.cam.ac.uk or www: http://www.ccdc.cam.ac.uk).

\section{Acknowledgements}

This work has been supported by CNPq, CAPES and FAPEMIG (Brazil).

\section{References}

[1] D. Coucouvanis, Prog. Inorg. Chem. 11 (1969) 233.

[2] P.J. Nieuwenhuizen, J. Reedijk, M. van Duin, W.J. McGill, Rubber Chem. Technol., Rubber Rev. 70 (1997) 368.

[3] M.J. Cox, E.R.T. Tiekink, Rev. Inorg. Chem. 17 (1997) 1.

[4] W. Hofmann (Ed.), Rubber Technology Handbook, Carl Hanser Verlag, Munich, 1989, pp. 242-259.

[5] L. Bateman, C.G. Moore, M. Porter, B. Saville, in: L. Bateman (Ed.), The Chemistry and Physics of Rubber-like Substances, first ed., Maclaren \& Sons, London, 1963, pp. 449-561.

[6] P.J. Nieuwenhuizen, S. Timal, J.G. Haasnoot, A.L. Spek, J. Reedijk, Chem. Eur. J. 3 (1997) 1846.

[7] P.J. Nieuwenhuizen, A.W. Ehlers, J.G. Haasnoot, S.R. Janse, J. Reedijk, E.J. Baerends, J. Am. Chem. Soc. 121 (1999) 163.

[8] K.H. Gustafsson, C.H. Fahlgren, J. Agric. Food Chem. 31 (1983) 461.

[9] H. van Lishaut, W. Schwack, J. AOAC Int. 83 (2000) 720.

[10] S.M. Dogheim, S.A.G. Alla, A.M. El-Marsafy, S. Fahmy, J. AOAC Int. 82 (1999) 948

[11] Y. Jianren, Z. Yongquan, J. Shuzshen, W. Zhengguo, Z. Fuzhen, Sci. Agric. Sin. 22 (1989) 76.

[12] G.D. Thorn, R.A. Ludwig (Eds.), The Dithiocarbamates and Related Compounds, Elsevier, Amsterdam, The Netherlands, 1962.

[13] M.J. Burkitt, H.S. Bishop, L. Milne, S.Y. Tsang, G.J. Provan, C.S.I. Nobel, S. Orrenius, A.F.G. Slater, Arch. Biochem. Biophys. 353 (1998) 73.

[14] A.K. Malik, W. Faubel, Pestic. Sci. 55 (1999) 965.

[15] E. Humeres, N.A. Debacher, M.M. de S. Sierra, J. Org. Chem. 64 (1999) 1807.

[16] T. Kamenosono, H. Shimada, T. Funakoshi, S. Kojima, Toxicology 170 (2002) 103.

[17] M. Motevalli, P. Ó Brien, J.R. Walsh, I.M. Watson, Polyhedron 15 (1996) 2801.

[18] B.L. Drue, Yu.N. Evtukhov, M.Ya. Rakhlin, Organomet. Chem. USSR 1 (1988) 357.

[19] D.M. Frigo, O.F.Z. Khan, P. O’Brien, J. Cryst. Growth 96 (1989) 989.

[20] B.L. Druz, A.I. Dyadenko, Yu.N. Evtukhov, M.Ya. Rakhlin, A.E. Rodionov, Inorg. Mater. 26 (1990) 24

[21] R.D. Pike, H. Cui, R. Kershaw, K. Dwight, A. Wold, T.N. Blanton, A.A. Wernburg, H.J. Gysling, Thin Solid Films 224 (1993) 221.

[22] E.I. Stiefel, in: E.I. Stiefel, K. Matsumoto (Eds.), Transition Metal Sulfur Chemistry: Biological and Industrial Significance, ACS Symposium Series, vol. 653, American Chemical Society, Washington, DC, 1996.

[23] M.R.L. Oliveira, H.P. Vieira, G.J. Perpétuo, J. Janczak, V.M. De Bellis, Polyhedron 21 (2002) 2243. 
[24] K. Hartke, Arch. Pharm. 299 (1966) 164.

[25] H.U. Hummel, U. Korn, Z. Naturforsch 44B (1989) 24.

[26] KUMA Diffraction, KUMA KM-4 CCD program package, Ver. 163, 2000, Wrocław, Poland.

[27] G.M. Sheldrick, SHELXTL Program, Siemens Analytical X-ray Instrument Inc., Madison WI, 1991.

[28] G.M. Sheldrick, SHELXL-97, Program for the Solution and Refinement of Crystal Structures, University of Göttingen, Göttingen, Germany, 1997.

[29] M.R.L. Oliveira, V.M. De Bellis, Trans. Met. Chem. 24 (1999) 127.

[30] D.A. Brown, W.K. Glass, M.A. Burke, Spectrochim. Acta A 32 (1976) 137.

[31] K. Nakamoto (Ed.), Infrared and Raman of Inorganic and Coordination Compounds, 3rd ed., Wiley, New York, 1978, p. 339 .
[32] M. Pomerantz, W.N. Chou, M.K. Witczak, C.G. Smith, J. Org. Chem. 52 (1987) 159.

[33] D. Coucouvanis, J.P. Fackler Jr., Inorg. Chem. 6 (1967) 2047.

[34] F.H. Allen, O. Kennard, D.G. Watson, L. Brammer, A.G. Orpen, J. Chem. Soc., Perkin Trans. 2 (1987) S1-S19.

[35] M.R.L. Oliveira, V.M. De Bellis, N.G. Fernandes, Struct. Chem. 8 (1997) 205.

[36] F.A. Cotton, C.B. Harris, Inorg. Chem. 7 (1968) 2140.

[37] R.J. Gillespie, J. Chem. Educ. 40 (1963) 295.

[38] R.J. Gillespie, Chem. Soc. Rev. 21 (1992) 59.

[39] V. Schomaker, K.N. Trueblood, Acta Cryst. B 24 (1968) 63.

[40] G.R. Desiraju, T. Solid (Eds.), The Weak Hydrogen Bond in Structural Chemistry and Biology, Oxford University Press, Oxford, 1999. 